\title{
Hand-foot Syndrome Secondary to Low-dose Docetaxel in a Breast Cancer Patient
}

\author{
Tariq Kewan $^{1}$, Mohammad Alomari ${ }^{2}$, Shrouq Khazaaleh ${ }^{2}$, Fahrettin Covut ${ }^{1}$, May Olayan ${ }^{1}$ \\ 1. Internal Medicine, Cleveland Clinic - Fairview Hospital, Cleveland, USA 2. Internal Medicine, Cleveland Clinic \\ Foundation, Cleveland, USA
}

Corresponding author: Tariq Kewan, kewant@ccf.org

\section{Abstract}

Docetaxel-induced hand-foot syndrome (HFS) at low doses is a very rare side effect that usually occurs in a dose-dependent manner. HFS can be managed with conservative measures and may need chemotherapy discontinuation. In this report we present a case of HFS in a breast cancer patient after one dose of docetaxel.

Categories: Dermatology, Oncology

Keywords: hand-foot syndrome, docetaxel

\section{Introduction}

Hand-foot syndrome (HFS), also known as palmoplantar erythrodysesthesia or Burgdorf's reaction, is a localized cutaneous reaction associated with the administration of several chemotherapeutic agents. Palms and soles erythema, swelling, and paresthesia are the most common presenting symptoms. The most common agents causing HFS are doxorubicin, 5-fluorouracil, capecitabine, vinorelbine, and methotrexate. HFS induced by docetaxel is a rare, dose-dependent adverse reaction [1-3].

\section{Case Presentation}

A 51-year-old female patient with a past medical history of stage IIIa (T1c, N2a, M0) right breast cancer, hepatitis $\mathrm{C}$ infection, and hypertension presented to emergency department (ED) with bilateral hand swelling, redness, and edema that started three days before coming to ED. Swelling and redness started only one day after starting docetaxel chemotherapy. She received a single dose of $117 \mathrm{mg}\left(75 \mathrm{mg} / \mathrm{m}^{2}\right)$ intravenous docetaxel. Also, she received prednisone before starting chemotherapy. She denied any recent fever or chills. Vitals signs were stable on admission; no fever was documented. Physical examination revealed bilateral swelling, redness, and tenderness of both hands up to the wrists (Figure 1). No upper limb weakness was found on physical examination. No skin rash was observed in other body parts.

Received 03/25/2019

Review began 03/25/2019 Review ended 03/28/2019 Published 04/06/2019

(c) Copyright 2019

Kewan et al. This is an open access article distributed under the terms of the Creative Commons Attribution License CC-BY 3.0., which permits unrestricted use, distribution, and reproduction in any medium, provided the original author and source are credited.

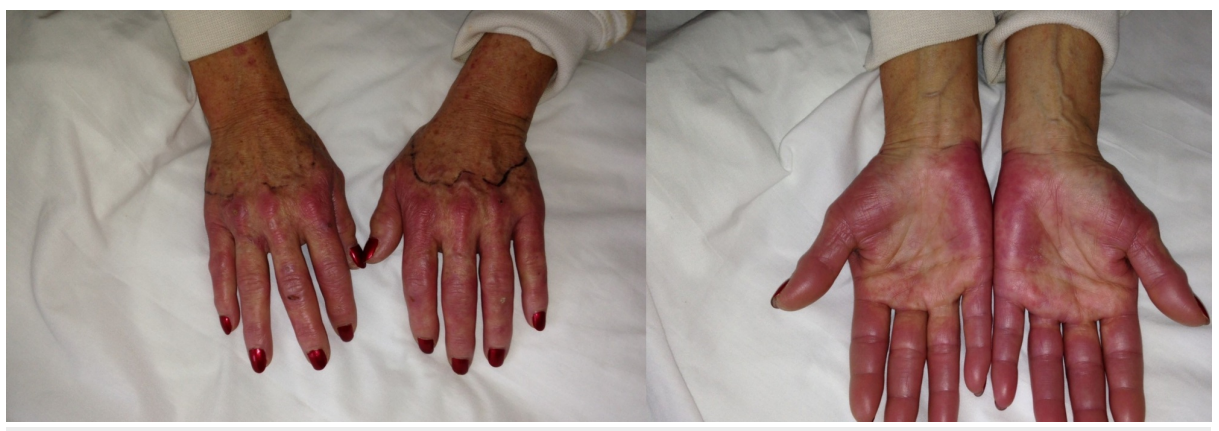

FIGURE 1: Dorsal and plantar view of both hands showing erythema and swelling bilaterally.

Lab investigation showed normal white blood cells count of 7.24 thousand cell/ul (normal range: 3.70-11.00 $\mathrm{k} / \mathrm{uL}$ ). Sepsis lactate was checked and was found to be $1.3 \mathrm{mmol} / \mathrm{L}$ (normal range: $0.5-2.0 \mathrm{mmol} / \mathrm{L}$ ). Basal metabolic panel, c-reactive protein (CRP), and erythrocyte sedimentation rate (ESR) on admission were unremarkable. Blood cultures were done and did not grow any microorganism. No imaging studies were done.

The patient was given vancomycin for one day without any improvement in skin rash or hand edema. On the next day antibiotics was stopped by the infectious disease team. She was then started on intravenous $40 \mathrm{mg}$ methylprednisolone. Swelling, redness, and pain started to improve $24 \mathrm{~h}$ after steroid initiation. The patient 
was discharged on prednisone $20 \mathrm{mg}$ three times daily for another seven days. She was diagnosed with HFS erythrodysesthesia.

\section{Discussion}

Hand-foot syndrome is a distinctive cutaneous toxicity affecting the palms and/or soles after exposure to certain chemotherapeutic agents. While most cases are induced by capecitabine, 5 -fluorouracil, and doxorubicin, with a reported incidence up to $50 \%$, docetaxel-induced HFS is considered rare and dosedependent, with only few cases reported to date [4-7]. Typically, it manifests with numbness, itching sensation, redness, and swelling of limbs [8].

Docetaxel is used in the management of locally advanced or metastatic breast carcinoma. The main side effect of docetaxel is bone marrow suppression; it can also lead to skin toxicity in a dose-dependent manner [9-10]. Few cases of low dose $\left(75 \mathrm{mg} / \mathrm{m}^{2}\right)$ docetaxel-induced HFS have been reported. In one case report, a 45-year-old female patient with breast cancer was reported to have docetaxel-induced HFS after receiving low dose $\left(75 \mathrm{mg} / \mathrm{m}^{2}\right)$ docetaxel [11]. Another case of docetaxel-induced HFS was reported in a 62 year-old female patient with invasive ductal breast cancer after receiving a similar dose [1].

Pathogenesis of docetaxel-induced HFS remains largely unknown. Rapidly dividing epidermal basal cells in the palms and soles are most sensitive to cytotoxic effects of docetaxel; making these areas more vulnerable for HFS. Other factors like temperature, pressure, and friction movements of hands and feet can increase the risk to HFS [12]. Docetaxel is metabolized by liver cytochrome P450 3A4 (CYP3A4) enzyme; inhibition of this enzyme decreases docetaxel metabolism and increases the risk for HFS [11-12]. In the present report, no other risk factors for HFS were identified.

Docetaxel-induced HFS is a clinical diagnosis. Skin biopsies can be used in some cases to differentiate it from cellulitis or other differential diagnoses. Our patient presented with a bilateral skin involvement making cellulitis diagnosis less likely [13]. Treatment of HFS is usually achieved by medication discontinuation and conservative measures such as ice bags, avoidance of sun exposure, and topical emollients. In severe cases, docetaxel can be stopped or restarted at lower doses if applicable [1, 3, 14]. Corticosteroids and pyridoxine have been found to be effective in HFS treatment and prophylaxis in some studies [15-16]. Our patient was managed by conservative measures and received oral steroids as well.

\section{Conclusions}

Low-dose docetaxel-induced HFS is very rare, and usually occurs in a dose-dependent manner. Although not serious, management of HFS improves the quality of life among active cancer patients. It usually responds to medication discontinuation and conservative measures. Physicians should be aware of this adverse event and the necessity to stop or at least decrease the dose of the offending agent expecting a complete resolution of symptoms afterwards.

\section{Additional Information \\ Disclosures}

Human subjects: Consent was obtained by all participants in this study. Conflicts of interest: In compliance with the ICMJE uniform disclosure form, all authors declare the following: Payment/services info: All authors have declared that no financial support was received from any organization for the submitted work. Financial relationships: All authors have declared that they have no financial relationships at present or within the previous three years with any organizations that might have an interest in the submitted work. Other relationships: All authors have declared that there are no other relationships or activities that could appear to have influenced the submitted work.

\section{References}

1. Tunio MA, AlAsiri M, Durrani SK: Hand foot syndrome secondary to low dose docetaxel. Int J Health Sci (Qassim). 2015, 9:335-337. 10.12816/0024699

2. Eich D, Scharffetter-Kochanek K, Eich HT, Tantcheva-Poor I, Krieg T: Acral erythrodysesthesia syndrome caused by intravenous infusion of docetaxel in breast cancer. Am J Clin Oncol. 2002, 25:599-602.

3. Harris CS, Wang D, Carulli A: Docetaxel-associated palmar-plantar erythrodysesthesia: a case report and review of the literature. J Oncol Pharm Pract. 2014, 20:73-80. 10.1177/1078155213475466

4. Zimmerman GC, Keeling JH, Lowry M, Medina J, Von Hoff DD, Burris HA: Prevention of docetaxel-induced erythrodysesthesia with local hypothermia. Int J Health Sci (Qassim). 2015, 9:335-337.

5. Saif MW: Capecitabine and hand-foot syndrome. Expert Opin Drug Saf. 2011, 10:159-169. 10.1517/14740338.2011.546342

6. Piedbois P, Rougier P, Buyse M, et al.: Efficacy of intravenous continuous infusion of fluorouracil compared with bolus administration in advanced colorectal cancer. J Clin Oncol. 1998, 16:301-308. 10.1200/JCO.1998.16.1.301

7. O’Brien ME, Wigler N, Inbar M, et al.: Reduced cardiotoxicity and comparableefficacy in a phase III trial of pegylated liposomal doxorubicin $\mathrm{HCl}$ (CAELYX/Doxil) versus conventional doxorubicin for first-line 


\section{Cureus}

treatment of metastatic breast cancer. Ann Oncol. 2004, 15:440-449.

8. Scheithauer W, Blum J: Coming to grips with hand-foot syndrome. Insights from clinical trials evaluating capecitabine. Oncology (Williston Park). 2004 , 8:1161-1168.

9. Ho MY, Mackey JR: Presentation and management of docetaxel-related adverse effects in patients with breast cancer. Cancer Manag Res. 2014, 6:253-259. 10.2147/CMAR.S40601

10. Yamamoto D, Yamamoto C, Tanaka K: Novel \& effective management of capecitabine induced hand foot syndrome. J Clin Oncol. 2004, 22:3099-3103. 10.1200/jco.2008.26.15_suppl.20615

11. Jain A, Dubashi B: Docetaxel-induced hand foot syndrome: "No dose is a safe dose" . J Pharmacol Pharmacother. 2012, 3:200-201.

12. Gurumurthi R, Nimmagadda RB, Mohan S: Docetaxel-induced hand and foot syndrome in a patient with metastatic breast carcinoma. Indian J Dermatol. 2013, 58:380-382. 10.4103/0019-5154.117309

13. Sivaramamoorthy C, Thientosapol ES, Tattersall MH: Hand-foot syndrome after treatment with docetaxel Med J Aust. 2009, 6:191.

14. Assi HA, Ayoub ZA, Jaber SM, Sibai HA, El Saghir NS: Management of paclitaxel-induced hand-foot syndrome. Breast Care (Basel). 2013, 8:215-217. 10.1159/000352097

15. Drake RD, Lin WM, King M, Farrar D, Miller DS, Coleman RL: Oral dexamethasone attenuates Doxil-induced palmar-plantar erythrodysesthesias in patients with recurrent gynecologic malignancies. Gynecol Oncol. 2004, 94:320-324. 10.1016/j.ygyno.2004.05.027

16. Chen M, Zhand L, Wang Q, Shen J: Pyridoxine for prevention of handfoot syndrome caused by chemotherapy: a systematic review. PLOS One. 2013, 8:72245. 